\title{
PELATIHAN OPERATOR CHAINSAW DAN TEKNIK PENEBANGAN DI PERUM PERHUTANI KESATUAN PEMANGKUAN HUTAN (KPH) TASIKMALAYA
}

\author{
Yayan Hendrayana, Ilham Adhya, Toto Supartono, Ika Karyaningsih dan Ai Nurlaela \\ Fakultas Kehutanan Universitas Kuningan, Indonesia \\ E-mail : yayan.hendrayana@uniku.ac.id
}

\begin{abstract}
Logging activities at Perum Perhutani are one of the determinants of the quality of wood produced. Mistakes in felling and errors in dividing the stems will greatly affect the quality of the wood produced. Therefore it requires operator knowledge and skills in carrying out these activities. This activity was carried out at the Tasikmalaya KPH Urug TPK which is part of the Tasikmalaya Forest Management Unit (BKPH). The activity was carried out on September 1, 2020. The activity began with an in-room presentation of chainsaw, usage theory, and logging techniques which was continued with practice in the field. The community service activity undertaken is to offer solutions in the form of training activities for chainsaw operators and logging techniques. The hope is that by knowing the types and parts of chainsaws as well as the proper felling techniques for operatots in the field, forest harvesting activities will run properly and correctly with optimum results.
\end{abstract}

Keywords: Logging, chainsaw, training, empowerment

\begin{abstract}
Abstrak
Kegiatan penebangan di Perum Perhutani menjadi salah satu penentu kualitas kayu yang diproduksi. Kesalahan dalam penebangan serta kesalahan dalam pembagian batang akan sangat berpengaruh terhadap kualitas kayu yang dihasilkan. Oleh karena itu dibutuhkan pengetahuan dan keterampilan operator dalam melakukan kegiatan tersebut. Kegiatan ini dilakukan di TPK Urug KPH Tasikmalaya yang termasuk pada Bagian Kesatuan Pemangkuan Hutan (BKPH) Tasikmalaya. Kegiatan dilaksanakan pada Tanggal 1 September 2020. Kegiatan diawali dengan pemaparan di dalam ruangan mengenai chainsaw, teori penggunaan, serta teknik penebangan yang dilanjutkan melakukan praktek di lapangan. Kegiatan pengabdian kepada masyarakat yang dilakukan adalah menawarkan solusi berupa kegiatan pelatihan bagi operator chainsaw dan teknik penebangan. Harapannya adalah dengan mengetahui jenis dan bagaian-bagian chainsaw serta teknik penebangan yang tepat bagi para operatot di lapangan maka kegiatan pemanenan hutan akan berjalan dengan baik dan benar dengan hasil yang optimum.
\end{abstract}

Kata Kunci : Penebangan, chainsaw, pelatihan, pemberdayaan

\section{PENDAHULUAN}

Pemanenan kayu merupakan serangkaian kegiatan kehutanan yang mengubah pohon menjadi bentuk yang dapat dipindahkan ke lokasi lain sehingga bermanfaat bagi kehidupan ekonomi dan kebudayaan masyarakat (Suparto, 1999). Menurut Suhartana et al (2014) kegiatan tersebut terdiri dari beberapa tahapan yaitu penebangan (felling), penyaradan (skidding or yarding), pembagian batang (cutting), pengangkutan (hauling) dan penimbunan kayu (unloading). Berdasarkan peralatan yang digunakan dalam penebangan terdapat 2 sistem yaitu sistem manual dan mekanis. Sistem penebangan manual menggunakan peralatan sederhana seperti gergaji tangan, kapak dan baji, sedangkan kegiatan penebangan secara mekanis menggunakan gergaji rantai (chainsaw). Gergaji rantai dapat digolongkan menjadi 2 jenis utama yaitu gergaji rantai 
untuk 2 orang (two menchainsaw) dan gergaji rantai untuk 1 orang (one man chainsaw) (Staaf \& Wiksten, 1984).

Gergaji rantai (chainsaw) adalah gergaji yang menggunakan mesin untuk menggerakkan rantai gergajinya. Pada awalnya orang menebang atau memotong kayu dengan gergaji manual. Setelah mesin ditemukan maka mesin diaplikasikan pada gergaji untuk mendapatkan produktivitas yang tinggi. Chainsaw pada awal pembuatan adalah chainsaw yang lebih besar dan berat (lebih dari $60 \mathrm{~kg}$ ) bahkan dioperasikan secara stasioner oleh lebih dari satu orang operator. Pada saat ini chainsaw sudah mengalami puluhan modifikasi bentuk dan aplikasi teknologi baru sehingga lahirlah chainsaw dengan teknologi mutakhir berupa chainsaw lebih kecil dan lebih ringan serta putaran mesin yang sangat cepat $(>15 \mathrm{rpm})$. Beberapa merk chainsaw terbaru tidak menggunakan mesin berbahan bakar minyak tetapi menggunakan tenaga listrik. Chainsaw terbaru juga dilengkapi dengan pengaman atau penangkap rantai, rem rantai, anti vibrasi, serta pelumasan otomatis. Teknologi bahan pada bilah (guide bar) semakin berkembang sehingga diaplikasi bilah yang lebih ringan tetapi tahan terhadap gesekan, tekanan dan panas. Semua hal ini dimaksudkan untuk memberikan kenyamanan dan keselamatan kerja bagi operator chainsaw sekaligus meningkatkan produktivitas kerjanya. (Matangaran, 2007).

Penebangan pohon yang dilakukan harus memperhatikan teknik penebangan dan sikap tubuh yang benar sehingga hasil kepecahan kayu dan beban kerja dapat berkurang. Menurut Sessions (2007), penebangan merupakan langkah pertama dalam proses mengkonversi pohon menjadi produk hutan yang lainnya. Hal tersebut menegaskan bahwa kegagalan dalam kegiatan penebangan mengakibatkan tersendatnya porses pemanenan hasil hutan kayu. Penebangan menjadi salah satu penentu kualitas kayu yang diproduksi. Kesalahan dalam penebangan dan kesalahan dalam pembagian batang akan sangat berpengaruh terhadap kualitas kayu yang dihasilkan. Kesalahan-kesalahan tesebut dapat mengakibatkan kerusakan pada kayu hasil tebangan bahkan dapat mengakibatkan kayu yang ditebang tidak dapat diproses lebih lanjut. Kegiatan penebangan dan pembagian batang yang efektif dan efisien diperlukan dalam pemanenan hasil hutan kayu. Salah satu unit manajemen Perum Perhutani di wilayah Regional Jawa Barat dan Banten adalah Kesatuan Pemangkuan Hutan (KPH) Tasikmalaya yang dibentuk berdasarkan SK. Direksi Nomor. 910/KPTS/Dir/2013 tentang Pembagian Kawasan Hutan Pada Kesatuan Pemangkuan Hutan Tasikmalaya, luas hutan 43.974,61 Ha meliputi kawasan hutan yang berada di Kabupaten Tasikmalaya dan Kota Tasikmalaya Propinsi Jawa Barat. Berdasarkan letak geografis terletak pada 7'03'00' s/d 7'48'10 Lintang Selatan dan 107'54'32' s/d 108P'28'5' Bujur Timur. . Kawasan Pengelolaan Hutan Perum Perhutani KPH Tasikmalaya seluas 43.974,61 Ha.

Luaran yang dihasilkan dari kegiatan pengabdian kepada masyarakat ini adalah diperolehnya pengetahuan tentang cara penggunaan chainsaw untuk operator dan teknik penebangan pada saat pemanenan kayu. Luaran lainnya adalah publikasi jurnal pengabdian masyarakat. Dampak sosial dengan adanya pelatihan operator chainsaw dan teknik penebangan ini khususnya bagi para operator di lapangan adah mereka akan terbiasa dengan penggunaan chainsaw dan teknik penebangan yang baik dan benar. 


\section{METODE PELAKSANAAN}

Kegiatan ini dilakukan di TPK Urug KPH Tasikmalaya yang termasuk pada Bagian Kesatuan Pemangkuan Hutan (BKPH) Tasikmalaya. Kegiatan dilaksanakan pada Tanggal 1 September 2020. Kegiatan diawali dengan pemaparan di dalam ruangan mengenai chainsaw, teori penggunaan, serta teknik penebangan yang dilanjutkan melakukan praktek di lapangan.

\section{Pendekatan yang Ditawarkan}

Pendekatan yang ditawarkan dalam kegiatan ini adalah melakukan pelatihan dan mempraktekkan cara penggunaan chainsaw dan teknik penebangan di lapangan. Adapun tahapan yang akan dilaksanakan sebagai berikut:

1. Pelatihan dan praktek penggunaan chainsaw

Pelatihan dilakukan oleh dosen Fakultas Kehutanan Universitas Kuningan, sehingga diharapkan operator mendapatkan pengetahuan tentang cara penggunaan chainsaw yang baik dan benar.

Bahan-bahan yang digunakan dalam penelitian adalah chainsaw, Alat Pelindung Diri (APD) dan log batang pohon.

2. Pelatihan dan Praktek Teknik Penebangan

Praktek teknik penebangan oleh tim Fakultas Kehutanan kepada operator tebang (blandong) dengan membuat dengan meragakan cara dan teknik penebangan.

\section{Partisipasi Mitra dalam Pelaksanaan Kegiatan}

Kegiatan ini melibatkan para karyawan yang bekerja di Perum Perhutani KPH Tasikmalaya sebagai mitra Fakultas Kehutanan Universitas Kuningan dengan harapan materi serta praktek yang deberikan akan mampu dipahami dan dapat dilaksanakan dalam pekerjaannya sehari-hari. Kegiatan yang dilaksanakan ini merupakan kegiatan yang biasa dilakukan oleh para karyawan namun akan lebih menyegarkan ingatan para karyawan akan hal dan aturan serta cara yang terbaru. Keberlanjutan dari kegiatan ini adalah para karyawan selalu ingat dan mampu melakukan tahapan dan teknik yang telah diberikan pada pekerjaannya masing-masing.

\section{HASIL DAN PEMBAHASAN \\ Operator chainsaw}

Penebangan dan pemotongan pohon yang dilaksanakan oleh operator chainsaw merupakan salah satu aktifitas pemanenan hasil hutan. Kegiatan pemanenan hasil hutan berupa kayu memegang peranan penting dalam kegiatan pengelolaan hutan. Kegiatan pemanenan hasil hutan (harvesting) sebagai bagian dari pengelolaan hutan juga harus memperhatikan asas kelestarian hutan tersebut. Kegiatan pemanenan hasil hutan dapat optimal dan lestari apabila didalam perencanaannya matang dalam berbagai aspek.

Operator chainsaw, bersama-sama unit lainnya di dalam sebuah kesatuan manajemen, merupakan salah satu ujung tombak perusahaan dalam mensukseskan tujuan sebuah usaha. Pengetahuan, ketrampilan dan sikap kerja yang baik dan benar dari seorang operator chainsaw menjadi ketentuan penting yang tidak dapat diabaikan demi tercapainya target yang diinginkan. Untuk itu diperlukan upaya peningkatan kapasitas (capacity building) operator chainsaw melalui kegiatan in, diharapkan dapat secara kumulatif bersama komponen lain akan meningkatkan performa perusahaan. 


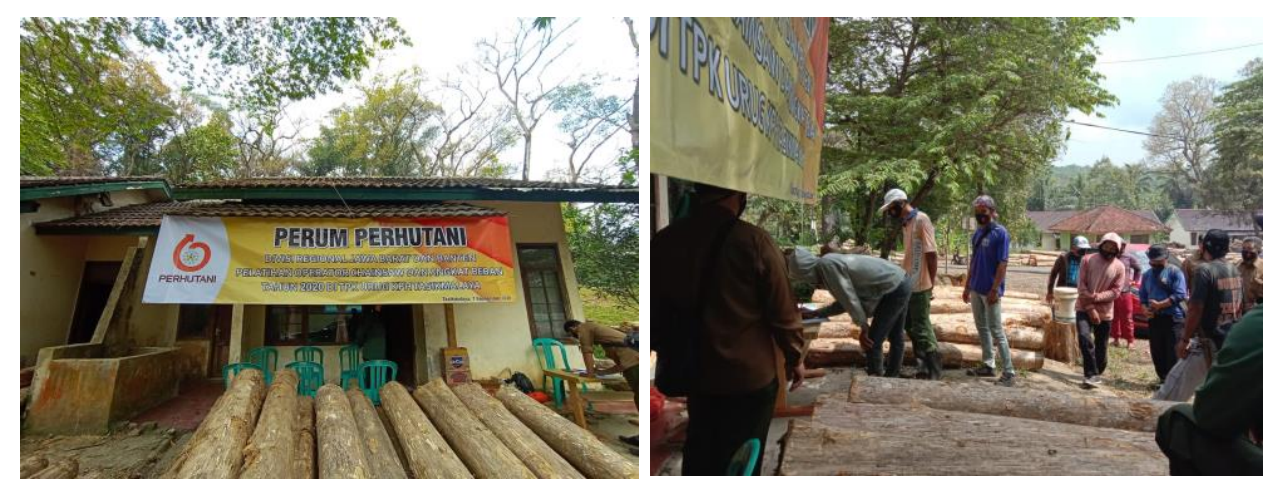

Gambar 1. Tahap persiapan

Setelah mengikuti pelatihan ini karyawan Perum Perhutani KPH Tasikmalaya diharapkan dapat memahami dan melaksanakan peraturan keselamatan, penggunaan gergaji mesin, dan prosedur penebangan dan pembagian batang pohon sesuai teknik dan standar yang tepat dan efisien. Selanjutnya setelah selesai mengikuti diklat ini, diharapkan para karyawan mampu ; (1) Memahami peraturan keamanan dan keselamatan kerja khususnya yang berhubungan dengan penggunaan gergaji mesin (chainsaw); (2) Mempersiapkan penggunaan dan perawatan gergaji mesin sesuai dengan standar yang telah ada; (3) Menebang pohon secara tepat dan aman; (4) Memotong kayu secara akurat sesuai dengan standar menggunakan teknik yang aman dan efisien; (5) Melakukan teknik pertolongan pertama yang sesuai dengan keselamatan operator chainsaw.

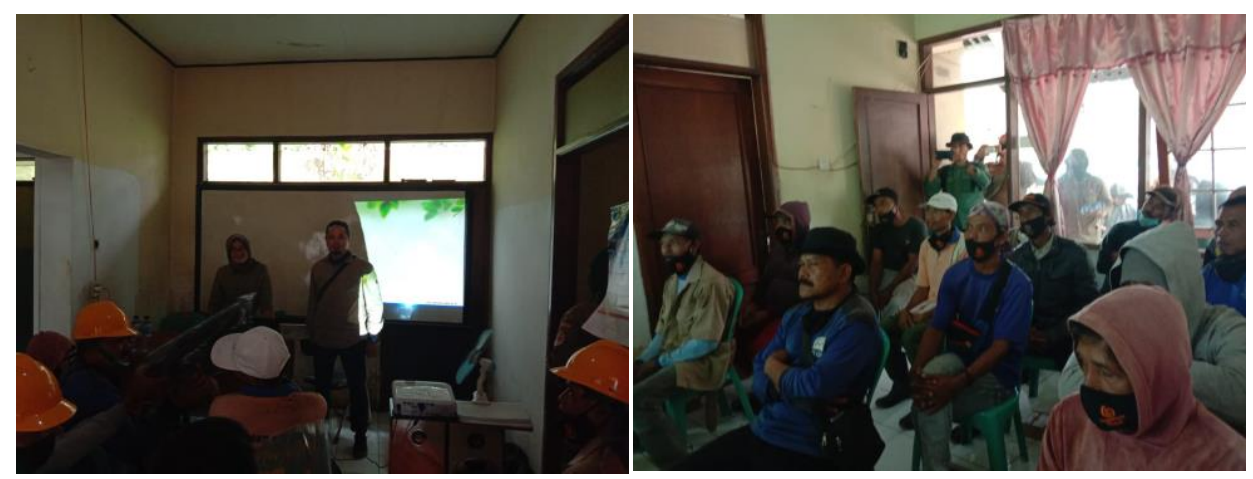

Gambar 2. Penyampaian materi

Chainsaw digunakan pada saat penebangan dan pembagian batang. Menurut Haryanto (1996), beberapa keuntungan penggunaan chainsaw sebagai berikut : (1) Mengurangi biaya penebangan dan pembagian batang; (2) Menciptakan tunggak yang lebih rendah; (3) Pekerjaan lebih cepat selesai; (4) Lebih efisien dan lebih murah untuk penebangan dan pembagian batang; (5) Mengurangi kecelakaan kerja. Kebutuhan jumlah chainsaw dapat dihitung berdasarkan pada waktu penyelesaian pekerjaan (jam kerja), volume kerja (m3) dan kapasitas produksi alat yang digunakan (m3/jam).

Chainsaw sangat membantu memudahkan dan mempercepat pelaksanaan kegiatan penebangan tetapi penggunaan chainsaw dengan jumlah kebutuhan yang tidak memadai dapat memperlambat pekerjaan sedangkan jika berlebihan dapat menyebabkan ketidak- 
efisienan penggunaan chainsaw karena adanya pemborosan biaya dalam pengadaan dan pemeliharaannya

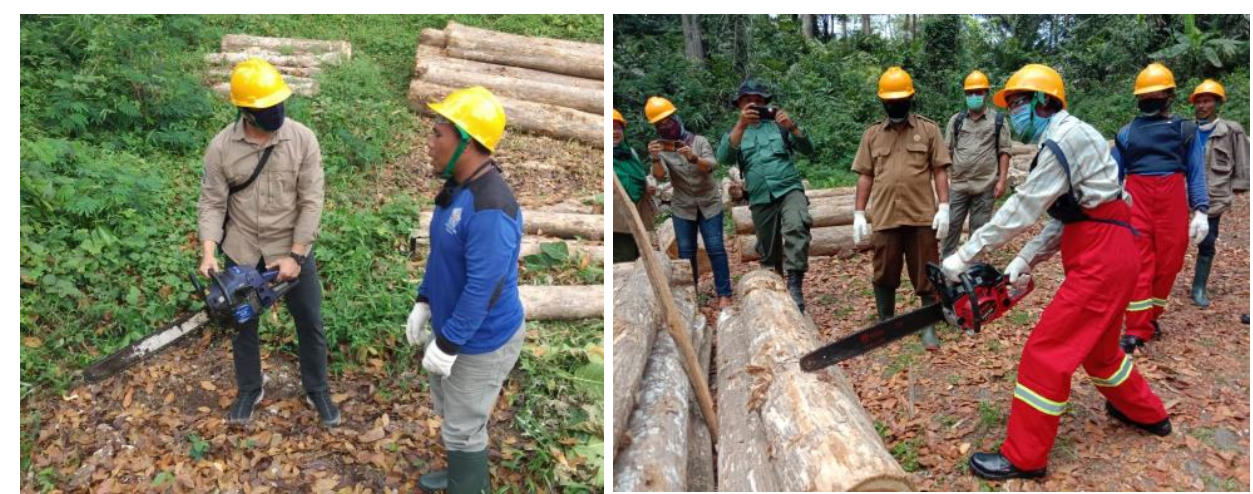

Gambar 3. Penggunaan chainsaw

Menurut Sukanda dan Endom (2008), tindakan yang perlu dilakukan sebelum gergaji rantai dipergunakan antara lain : (1) Pemasangan keping rantai dan rantai; (2) Pengisian bahan bakar; (3) Pengisian minyak pelumas rantai; (4) Menghidupkan dan mematikan mesin; (5) Pelumasan rantai.

Penggunaan gergaji rantai:

1. Menebang pohon pada kegiatan penjarangan

Penjarangan adalah menebang pohon yang kurang baik untuk memberikan ruang tumbuh yang lebih baik pada pohon yang lebih baik pertumbuhaannya meningkat. Menebang pohon pada kegiatan penjarangan tidak terlalu sulit karena pohon yang akan ditebang telah ditandai terlebih dahulu dan pohon yang ditebang berdiameter kecil $(<20 \mathrm{~cm})$ sehingga gergaji rantai yang dipergunakan cukup dengan gergaji rantai kelas ringan.

2. Menebang pohon pada kegiatan pemanenan di hutan tanaman

Untuk menebang pohon pada kegiatan pemanenan di hutan tanaman digunakan gergaji rantai kelas sedang karena diameter pohon yang ditebang rata-rata $22 \mathrm{~cm}$. Penebangan dilakukan oleh regu tebang yang terdiri dari operator (penebang) dan 4 orang pembantu untuk mengumpulkan kayu. Prestasi kerja satu regu tebang di hutan tanaman dengan diameter $22 \mathrm{~cm}$ menggunakan gergaji rantai kelas sedang adalah 15 $\mathrm{m} 3$ per hari atau 2,14 m3 per jam.(Dulsalam \& Tinambunan, 2006).

3. Menebang pohon pada kegiatan pemanenan di hutan alam

Untuk menebang pohon pada kegiatan pemanenan digunakan gergaji rantai kelas berat Penebangan dilakukan oleh regu tebang yang terdiri dari operator (penebang) dan pembantu. Produktivitas kerja satu regu tebang di hutan alam untuk menebang pohon diameter $80 \mathrm{~cm}$ menggunakan gergaji rantai kelas berat. 


\section{Teknik Penebangan}

Pada dasarnya kegiatan penebangan pohon terdiri dari 3 kegiatan yaitu :

1. Persiapan dan pembersihan tumbuhan bawah, tujuannya adalah untuk mempermudah kegiatan penebangan dan mencegah terjadinya kecelakaan selama kegiatan penebangan

2. Penentuan arah rebah

3. Pembuatan takik rebah dan takik balas

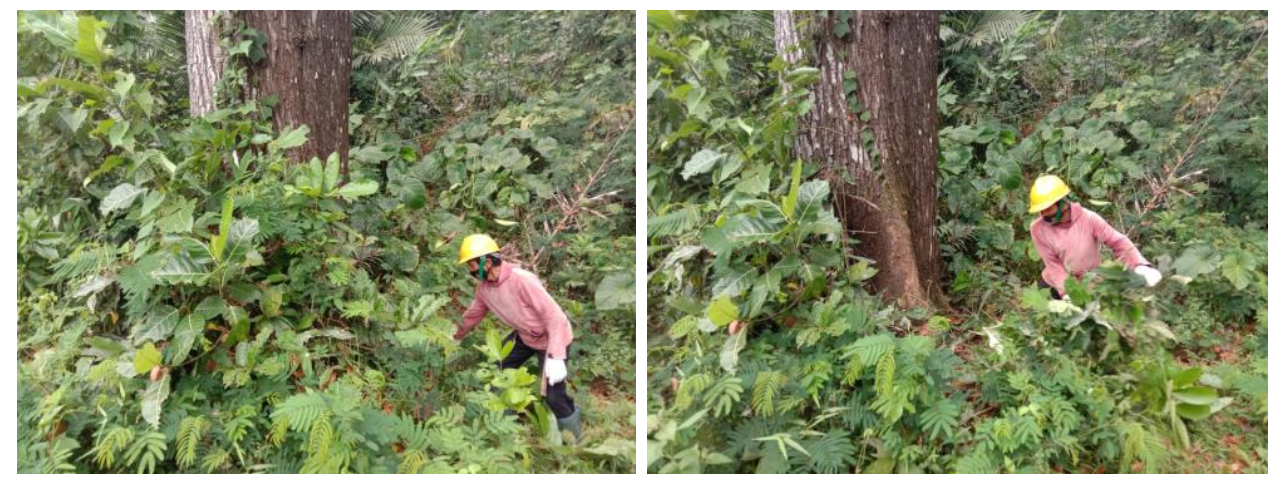

\section{Gambar 4. Pembersihan lokasi}

Teknik penebangan terdiri dari :

1. Membuat takik rebah : merupakan garis pemotongan kayu yang digunakan untuk merebahkan pohon yang dipotong.

Takik rebah terdiri dari 2 bagian utama yaitu alas takik dan atap takik. Alas takik dibuat terlebih dahulu dengan kedalaman berkisar antara 1/5 - 1/3 diameter pohon (dbh). Setelah membuat alas takik, selanjutnya membuat atap takik dengan sudut 45 derajat dari alas takik. Hasilnya berupa potongan yang disebut dengan mulut takik

2. Membuat takik balas : merupakan garis pemotongan balasan ( 90 derajat dari takik rebah) yang digunakan sebagai tahap pemotongan akhir dalam perebahan pohon. Panjang takik balas diperkirakan1/10 diameter pohon dari garis perpanjangan alas takik. Takik balas dibuat dengan cara memotong pohon secara horizontal pada ketinggian diatas sampai kayu engsel

Memantau kayu engsel : kayu engsel adalah bagian kayu antara takik rebah dan takik balas. Kayu ini lebarnya kurang lebih 1/10 diameter pohon. Fungsi dari kayu engsel adalah sebagai kemudi dalam mengarahkan rebahnya pohon
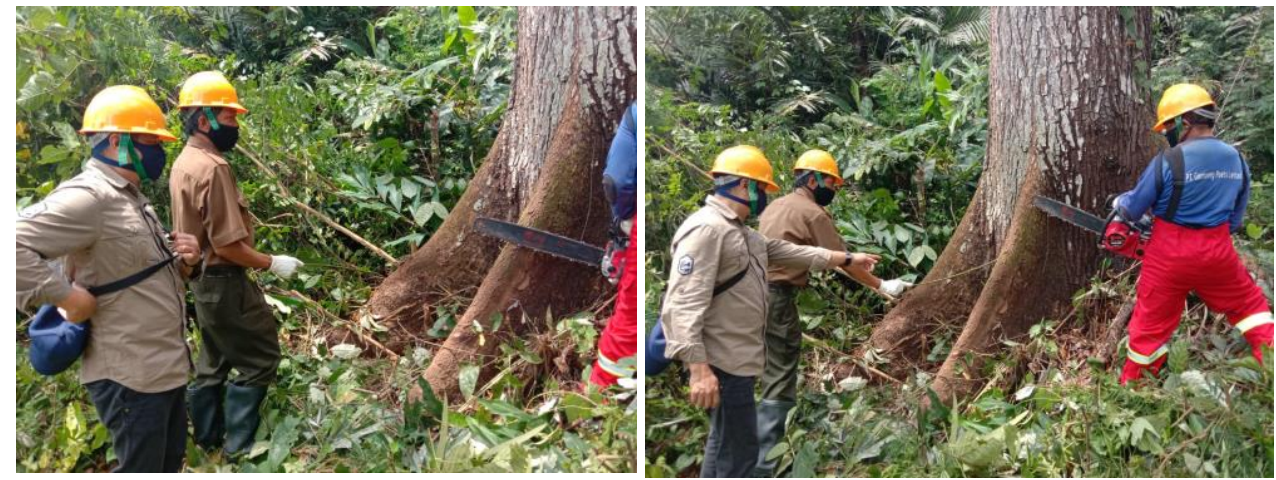

Gambar 5. Proses Penebangan 


\section{SIMPULAN}

Pelatihan operator chainsaw dan teknik penebangan mendapat respon yang cukup baik dari para operator chainsaw yang merupakan karyawan Perum Perhutani KPH Tasikmalaya. Dengan adanya pengetahuan ini maka pengetahuan para operator meningkat sehingga akan meningkatkan kinerjanya.

\section{SARAN}

Diharapkan pelatihan seperti ini tetap dilaksanakan secara rutin. Dikarenakan perkembangan teknologi yang terus berkembang dan sebagai evaluasi capaian dari tahunketahun. Perlu diadakan kembali pelatihan pemanfaatan teknologi yang lebih luas, bukan hanya untuk meningkatkan jangkauan pemasaran, tetapi untuk pengelolaan dan distribusi yang efektif dan efisien..

\section{UCAPAN TERIMA KASIH}

Ucapan terima kasih disampaikan kepada Fakultas Kehutanan Universitas Kuningan yang telah memberikan kesempatan kepada kami untuk melakukan kegiatan pengabdian kepada masyarakat ini. Ucapan terima kasih juga disampaikan kepada Perum Perhutani KPH Tasikmalaya atas kerjasamanya dalam kegiatan ini.

\section{DAFTAR PUSTAKA}

Dulsalam dan D.Tinambunan. 2006. Produktivitas dan Biaya Pemanenan Hutan Tanaman: Studi Kasus di PT. Musi Hutan Persada, Sumatera Selatan. Jurnal Penelitian Hasil Hutan 24(3):251-266. Bogor

Haryanto, 1996. Pemanenan Hasil Hutan. Buku 2: Penebangan. Yayasan Pembina Fakultas Kehutanan Universitas Gajah Mada. Yogyakarta

Matangaran, J.R. 2007. Pengetahuan tentang Chainsaw (Prinsip Kerja dan Pengoperasian). Bogor: Fakultas Kehutanan IPB.

Sessions, Johon. (2007). Harvesting Operations in the Tropics. Springer. Corvallis

Staaf, K.A.G., N.A. Wiksten. 1984. Tree Harvesting Techniques. Martinus Nijhoff/Dr.W. Junk Publishers. Dordrecht, The Netherlands.

Suhartana, S., Yuniawati dan Dulsalam. 2014. Luas petak tebang optimal pemanenan kayu di areal hutan tanaman rawa gambut. Jurnal Penelitian Hasil Hutan. 32(2): 175-188.

Sukanda dan Endom W, 2008. Standardisasi Gergaji Rantai Untuk Penebangan Pohon. Prosiding PPI Standardisasi. Hal. 1-11.

Suparto, R.S. 1999. Pemanenan Kayu. IPB Press. Bogor 